\title{
Rev-erbs: Integrating Metabolism Around the Clock
}

\author{
Mitchell A. Lazar
}

\begin{abstract}
Mammalian circadian and metabolic physiologies are intertwined, and the nuclear Rev-erb $\alpha$ is a key transcriptional link between them. Rev-erb $\alpha$, and the highly related Rev-erb $\beta$, are potent transcriptional repressors that are required for the function of the core mammalian molecular clock. The Rev-erbs are also critical regulators of clock output in metabolic cells and tissues. This chapter focuses on the physiological functions of Rev-erb $\alpha$ and $\beta$ in regulating circadian rhythms and metabolism in mammalian tissues.
\end{abstract}

\section{Introduction}

Much of biology is conducted with rhythms that have a phase of approximately $24 \mathrm{~h}$, matching the duration of a day on planet Earth (Huang et al. 2011). The genetic basis of these circadian rhythms was unveiled in the fruit fly, Drosophila melanogaster, where the clock mechanism involves feedback regulation by factors whose own expression exhibit circadian rhythmicity (Rosbash et al. 1996). These factors function as transcriptional regulators, and it is now recognized that most genomes, including those of all mammals that have been evaluated, are transcribed in a rhythmic manner (Schibler 2006).

The mammalian clock mechanism involves interconnected transcriptional and translational feedback loops, where the most well-understood positive regulator is a heterodimer of the basic helix-loop-helix (HLH) transcription factors BMAL1 and CLOCK (King and Takahashi 2000). In addition to positively regulating clock output genes, the BMAL1/CLOCK heterodimer activates the expression of two negative regulators. One is another bHLH heterodimer, comprised of the proteins PERIOD (PER) and CRYPTOCHROME (CRY), which interact with BMAL1/CLOCK to

M.A. Lazar, M.D., Ph.D. (四)

Division of Endocrinology, Diabetes, and Metabolism, Department of Medicine, Department of Genetics, and The Institute for Diabetes, Obesity, and Metabolism, Perelman School of Medicine at the University of Pennsylvania, Philadelphia, PA 19104, USA

e-mail: lazar@mail.med.upenn.edu 
interfere with its activity (King and Takahashi 2000). The second repressive loop is mediated by the Rev-erb nuclear receptors (NRs) $\alpha$ and $\beta$, of which Rev-erb $\alpha$ is the more highly functional (Everett and Lazar 2014). This chapter will focus on the Rev-erbs, particularly on the more well-studied Rev-erb $\alpha$.

\section{Repression of Transcription by Rev-erbs}

Rev-erbs belong to a large NR superfamily of ligand-regulated transcription factors (Evans 2013). Discovered in 1989 (Lazar et al. 1989; Miyajima et al. 1989), Rev-erb $\alpha$ was one of the first identified orphan NRs, i.e., a member of the family whose ligand was not predicted from earlier physiology and biochemical studies (Mullican et al. 2013). The highly related Rev-erb $\beta$ was identified in 1994 (Bonnelye et al. 1994; Dumas et al. 1994; Forman et al. 1994; Retnakaran et al. 1994). Molecular heme has been identified as the endogenous ligand for Rev-erb $\alpha$ and Rev-erb $\beta$ (Raghuram et al. 2007; Yin et al. 2007). Although the physiological function of this regulation is not well understood, the ability to sense heme levels may position Rev-erb as a mediator of metabolic effects on metabolism.

Rev-erbs bind sequence-specifically to DNA, with the preferred binding site consisting of the classical NR half-site AGGTCA flanked by an A/T-rich $5^{\prime}$ sequence (Harding and Lazar 1993). This binding site is referred to as the RevRE or as the RORE, as it is also bound by the Retinoic Acid Receptor-related Orphan Receptor (ROR; Giguere et al. 1994). The DNA-binding domain (DBD) of Rev-erb $\alpha$ binds in the major groove of the AGGTCA half-site, whereas a C-terminal extension makes minor groove contacts with the A/T-rich $5^{\prime}$ sequence (Zhao et al. 1998). Rev-erbs bind as a monomer to this site but bind even more tightly as a dimer to a direct repeat with a 2 base pair spacer, referred to as the RevDR2 (Harding and Lazar 1995).

Rev-erbs lack the C-terminal region that is required for ligand-dependent transcriptional activation by other NRs (Glass and Rosenfeld 2000). Thus, they function primarily as potent repressors of transcription when bound to DNA (Zamir et al. 1997), interacting constitutively with the Nuclear Corepressor 1 (NCoR; Horlein et al. 1995; Zamir et al. 1996). NCoR is a large protein $(2270 \mathrm{kDa})$ with inherent repressive function as well as several short helical domains that specifically interact with NRs, called the corepressor-NR (CoRNR) boxes (Hu and Lazar 1999). Heme further stabilizes its interaction with full-length, endogenous NCoR (Raghuram et al. 2007; Yin et al. 2007). In addition to serving as a heme sensor, the Rev-erb activity may also be sensitive to the oxidation state of the heme iron (Marvin et al. 2009). To bind NCoR stably enough to actively repress transcription, two Rev-erb $\alpha$ molecules must interact with CoRNR peptides from NCoR; this interaction can occur at the RevDR2 site, which the Rev-erbs bind cooperatively as a dimer, or at two Revre/RORE sites bound independently by Rev-erb monomers (Zamir et al. 1997). 
NCoR represses transcription by nucleating a large multiprotein repressor complex, which impacts the epigenome and the function of core transcriptional factors and RNA polymerase II (Guenther et al. 2000; Yoon et al. 2003). Stoichiometric components of the NCoR complex include Transducin Beta-Like 1 (TBL1), G-protein Pathway Suppressor 2 (GPS2), and Histone Deacetylase 3 (HDAC3; Guenther et al. 2000; Zhang et al. 2002; Yoon et al. 2003). HDAC3 is of particular interest, because it is an epigenomic modulator that deacetylates lysine residues in the tails of nucleosomal histone proteins to create a repressive chromatin environment (Haberland et al. 2009). NCoR and HDAC3 are both required for Rev-erb $\alpha$ to repress Bmall gene transcription (Yin and Lazar 2005), and both NCoR and HDAC3 are associated with Rev-erb $\alpha$ at thousands of DNA binding sites genome wide in the mouse liver (Feng et al. 2011).

\section{Circadian Biology of Rev-erbs}

In 1998, Rev-erb $\alpha$ was noted to one of the genes that oscillates within the circadian transcriptome of mammalian cells cycling in tissue culture (Balsalobre et al. 1998). In mice Rev-erb $\alpha$ mRNA expression is robustly circadian in multiple tissues (Yang et al. 2006), and genetic deletion of Rev-erb $\alpha$ shortens the period of behavioral rhythms by $\sim 30 \mathrm{~min}$ in the absence of daily light cues (Preitner et al. 2002). Rev-erb $\alpha$ modulates the rhythmicity of additional circadian regulators, including Clock (Crumbley and Burris 2011), Cryl (Ukai-Tadenuma et al. 2011), Nfil3/ E4Bp4 (Duez et al. 2008), and Npas2 (Crumbley et al. 2010) and thus has a major influence on the cell-autonomous molecular timing system. Indeed, constitutive expression of Rev-erbo in mouse liver represses the majority of cycling transcripts (Kornmann et al. 2006). Importantly, ablation of both Rev-erbo and $\beta$ abrogates circadian gene expression in mouse embryonic fibroblasts, demonstrating a fundamental requirement for the Rev-erbs (Bugge et al. 2012). Moreover, genetic mutation of Rev-erb $\alpha$ and $\beta$ caused arrhythmic behavior in mice (Cho et al. 2012). Therefore Rev-erb $\alpha$ and $\beta$ are both required components of the core clock machinery. Loss of either Rev-erb alone is insufficient to abolish circadian rhythms, indicating that their clock functions are redundant, although Rev-erb $\alpha$ is more critical because its absence modestly disrupts normal circadian rhythms whereas the loss of Rev-erb $\beta$ does not.

\section{Rev-erbo and Metabolism}

Circadian rhythms and metabolism are highly intertwined (Eckel-Mahan and Sassone-Corsi 2013), and indeed Rev-erb $\alpha$ regulates metabolic function in many tissues. In the liver, Rev-erb $\alpha$ regulates cholesterol and bile acid metabolism (Duez et al. 2008; Le Martelot et al. 2009), and more recently has been observed to play a 
key role in the circadian regulation of triglyceride metabolism (Feng et al. 2011). Rev-erb $\alpha$ binds widely and robustly to the genome at ZT10, when its expression is maximal; however, it binds to very few sites when its expression is at a nadir, such as at ZT22. This genomic binding is enriched at genes involved in lipid metabolism and, indeed, mice lacking Rev-erb $\alpha$ have mild fatty liver, or hepatic steatosis (Feng et al. 2011). The oscillatory expression of Rev-erb $\alpha$ regulates circadian gene expression directly at target genes with strong binding motifs, whose circadian expression is antiphase to that of Rev-erb $\alpha$, as well as indirectly by repression of another circadian repressor called E4BP4, whose target genes are expressed in phase with Rev-erb $\alpha$ (Fang et al. 2014). The liver cistrome of Rev-erb $\beta$ is quite similar, and knockdown of Rev-erb $\beta$ in livers of Rev-erb $\alpha$ null mice caused a more markedly fatty liver (Bugge et al. 2012). NCoR and HDAC3 bind to the genome at the vast majority of Rev-erb sites and, indeed, ablation of either NCoR or HDAC3 in mouse liver leads to marked hepatic steatosis (Knutson et al. 2008; Sun et al. 2012, 2013).

Studies of adipocyte differentiation in cultured cell lines have suggested that Rev-erb $\alpha$ plays an important role in adipocyte differentiation (Chawla and Lazar 1993; Fontaine et al. 2003; Wang and Lazar 2008), yet white adipose tissue (WAT) mass was not reduced in mice lacking Rev-erb $\alpha$ (Chomez et al. 2000; Delezie et al. 2012), indicating that Rev-erbo is not absolutely required for adipocyte formation in vivo. Rev-erb $\alpha$ may play a role in brown adipose tissue (BAT), which is a major site of thermogenesis (Gerhart-Hines et al. 2013). Circadian expression of Rev-erbo in BAT peaks at ZT10, which is antiphase to the circadian rhythm of body temperature. Mice lacking Rev-erb $\alpha$ have a higher nadir in body temperature, at least in part due to derepression of Uncoupling Protein 1 (UCP1), which is a circadian target of Rev-erb $\alpha$ and constitutively high in the BAT of mice genetically lacking Rev-erb $\alpha$ (Gerhart-Hines et al. 2013). Mice also have an increased vulnerability to cold temperature at times of day when Rev-erb $\alpha$ levels are high; this vulnerability is ameliorated in the absence Rev-erb $\alpha$ (Gerhart-Hines et al. 2013).

A role for Rev-erb $\alpha$ in skeletal myocytes was first identified in $\mathrm{C} 2 \mathrm{C} 12$ cultured myoblasts, where Rev-erb $\alpha$ represses the expression of genes involved in muscle cell differentiation (Downes et al. 1995). Rev-erb $\alpha$ mRNA expression is circadian manner in mouse skeletal muscle (Yang et al. 2006), and loss of Rev-erb $\alpha$ function reduces mitochondrial content and function, leading to an impaired exercise capacity (Woldt et al. 2013). It should be noted that the transcriptomic changes in muscle are not observed in liver or BAT and thus reflect tissue-specific functions of Rev-erbo.

Rev-erbo is also expressed in a circadian manner in the pancreatic islets and plays a role in the function of insulin-producing $\beta$-cells and glucagon-producing $\alpha$-cells (Vieira et al. 2012, 2013). Islets isolated at the peak of Rev-erb $\alpha$ expression have higher levels of glucose-stimulated insulin secretion (Vieira et al. 2012), and Rev-erb $\alpha$ also promotes glucagon secretion in $\alpha$-cells of the pancreas (Vieira et al. 2013). 
Inflammatory cells are increasingly linked to metabolic function (Osborn and Olefsky 2012), and Rev-erb $\alpha$ mediates the circadian gating of the LPS-induced endotoxic response (Gibbs et al. 2012). Genome-wide studies of Rev-erb $\alpha$ and Rev-erb $\beta$ cistromes and transcriptomes suggest that Rev-erb $\alpha$ influences macrophage gene expression at bindings sites marked by hematopoietic transcription factors, including PU.1 (Lam et al. 2013).

\section{Conclusions}

The nuclear receptor Rev-erb $\alpha$ acts in a tissue-specific manner to regulate circadian rhythms as well as metabolism, in some cases acting redundantly with Rev-erb $\beta$. A critical question is whether Rev-erb $\alpha$ can be targeted for therapeutic purposes. Synthetic pharmacological agonists have been developed (Grant et al. 2010; Solt et al. 2012), yet the tissue-specific complexity of Rev-erb biology raises major challenges to human therapeutics. Perhaps the dramatic circadian expression of Rev-erbs can be exploited by timing drug delivery to selectively impact their specific and beneficial functions in integration of metabolism and the circadian clock.

Acknowledgments I thank members of my research group, particularly Logan Everett, for helpful discussions. Research on Rev-erb in my laboratory is supported by NIH grant R01 DK45586 (MAL).

Open Access This chapter is distributed under the terms of the Creative Commons AttributionNoncommercial 2.5 License (http://creativecommons.org/licenses/by-nc/2.5/) which permits any noncommercial use, distribution, and reproduction in any medium, provided the original author(s) and source are credited.

The images or other third party material in this chapter are included in the work's Creative Commons license, unless indicated otherwise in the credit line; if such material is not included in the work's Creative Commons license and the respective action is not permitted by statutory regulation, users will need to obtain permission from the license holder to duplicate, adapt or reproduce the material.

\section{References}

Balsalobre A, Damiola F, Schibler U (1998) A serum shock induces circadian gene expression in mammalian tissue culture cells. Cell 93:929-937

Bonnelye E, Vanacker JM, Desbiens X, Begue A, Stehelin D, Laudet V (1994) Rev-erb-beta, a new member of the nuclear receptor superfamily, is expressed in the nervous-system during chicken development. Cell Growth Differ 5:1357-1365

Bugge A, Feng D, Everett LJ, Briggs ER, Mullican SE, Wang FF, Jager J, Lazar MA (2012) Rev-erb alpha and Rev-erb beta coordinately protect the circadian clock and normal metabolic function. Genes Dev 26:657-667 
Chawla A, Lazar MA (1993) induction of Rev-erbA-alpha, a nuclear hormone receptor-related transcriptional activator, during adipocyte differentiation. J Biol Chem 268:16265-16269

Cho H, Zhao X, Hatori M, Yu RT, Barish GD, Lam MT, Chong LW, DiTacchio L, Atkins AR, Glass CK, Liddle C, Auwerx J, Downes M, Panda S, Evans RM (2012) Regulation of circadian behaviour and metabolism by REV-ERB-alpha and REV-ERB-beta. Nature 485:123-127

Chomez P, Neveu I, Mansen A, Kiesler E, Larsson L, Vennstrom B, Arenas E (2000) Increased cell death and delayed development in the cerebellum of mice lacking the Rev-erbA alpha orphan receptor. Development 127:1489-1498

Crumbley C, Burris TP (2011) Direct regulation of CLOCK expression by REV-ERB. PLoS One 6:e17290

Crumbley C, Wang YJ, Kojetin DJ, Burris TP (2010) Characterization of the core mammalian clock component, NPAS2, as a REV-ERB alpha/ROR alpha target gene. J Biol Chem 285:35386-35392

Delezie J, Dumont S, Dardente H, Oudart H, Grechez-Cassiau A, Klosen P, Teboul M, Delaunay F, Pevet P, Challet E (2012) The nuclear receptor REV-ERB alpha is required for the daily balance of carbohydrate and lipid metabolism. FASEB J 26:3321-3335

Downes M, Carozzi AJ, Muscat GEO (1995) Constitutive expression of the orphan receptor, Rev-erbA-alpha, inhibits muscle differentiation and abrogates the expression of the myoD gene family. Mol Endocrinol 9:1666-1678

Duez H, Van Der Veen JN, Duhem C, Pourcet B, Touvier T, Fontaine C, Derudas B, Bauge E, Havinga R, Bloks VW, Wolters H, Van Der Sluijs FH, Vennstrom B, Kuipers F, Staels B (2008) Regulation of bile acid synthesis by the nuclear receptor Rev-erb alpha. Gastroenterology 135:689-698

Dumas B, Harding HP, Choi HS, Lehmann KA, Chung M, Lazar MA, Moore DD (1994) A new orphan member of the nuclear hormone-receptor superfamily closely-related to Rev-erb. Mol Endocrinol 8:996-1005

Eckel-Mahan K, Sassone-Corsi P (2013) Metabolism and the circadian clock converge. Physiol Rev 93:107-135

Evans RM (2013) Journal of Molecular Endocrinology 25th anniversary special issue. J Mol Endocrinol 51:E1-E3

Everett LJ, Lazar MA (2014) Nuclear receptor Rev-erb alpha: up, down, and all around. Trends Endocrinol Metab 25:586-592

Fang B, Everett LJ, Jager J, Brigges E, Armour SM, Feng D, Roy A, Gerhart-Hines Z, Sun Z, Lazar MA (2014) Circadian enhancers coordinate multiple phases of rhythmic gene transcription in vivo. Cell 159:1140-1152

Feng D, Liu T, Sun Z, Bugge A, Mullican SE, Alenghat T, Liu XS, Lazar MA (2011) A circadian rhythm orchestrated by histone deacetylase 3 controls hepatic lipid metabolism. Science 331:1315-1319

Fontaine C, Dubois G, Duguay Y, Helledie T, Vu-Dac N, Gervois P, Soncin F, Mandrup S, Fruchart JC, Fruchart-Najib J, Staels B (2003) The orphan nuclear receptor Rev-Erb alpha is a peroxisome proliferator-activated receptor (PPAR) gamma target gene and promotes PPAR gamma-induced adipocyte differentiation. J Biol Chem 278:37672-37680

Forman BM, Chen J, Blumberg B, Kliewer SA, Henshaw R, Ong ES, Evans RM (1994) Cross-talk among ROR-alpha-1 and the Rev-erb family of orphan nuclear receptors. Mol Endocrinol $8: 1253-1261$

Gerhart-Hines Z, Feng D, Emmett MJ, Everett LJ, Loro E, Briggs ER, Bugge A, Hou C, Ferrara C, Seale P, Pryma DA, Khurana TS, Lazar MA (2013) The nuclear receptor Rev-erb alpha controls circadian thermogenic plasticity. Nature 503:410-413

Gibbs JE, Blaikley J, Beesley S, Matthews L, Simpson KD, Boyce SH, Farrow SN, Else KJ, Singh D, Ray DW, Loudon ASI (2012) The nuclear receptor REV-ERB alpha mediates circadian regulation of innate immunity through selective regulation of inflammatory cytokines. Proc Natl Acad Sci USA 109:582-587

Giguere V, Tini M, Flock G, Ong E, Evans RM, Otulakowski G (1994) Isoform-specific aminoterminal domains dictate dna-binding properties of ROR-alpha, a novel family of orphan hormone nuclear receptors. Genes Dev 8:538-553 
Glass CK, Rosenfeld MG (2000) The coregulator exchange in transcriptional functions of nuclear receptors. Genes Dev 14:121-141

Grant D, Yin L, Collins JL, Parks DJ, Orband-Miller LA, Wisely GB, Joshi S, Lazar MA, Willson TM, Zuercher WJ (2010) GSK4112, a small molecule chemical probe for the cell biology of the nuclear heme receptor Rev-erb alpha. ACS Chem Biol 5:925-932

Guenther MG, Lane WS, Fischle W, Verdin E, Lazar MA, Shiekhattar R (2000) A core SMRT corepressor complex containing HDAC3 and TBL1, a WD40-repeat protein linked to deafness. Genes Dev 14:1048-1057

Haberland M, Montgomery RL, Olson EN (2009) The many roles of histone deacetylases in development and physiology: implications for disease and therapy. Nat Rev Genet 10:32-42

Harding HP, Lazar MA (1993) The orphan receptor Rev-erbA-alpha activates transcription via a novel response element. Mol Cell Biol 13:3113-3121

Harding HP, Lazar MA (1995) The monomer-binding orphan receptor Rev-erb represses transcription as a dimer on a novel direct repeat. Mol Cell Biol 15:4791-4802

Horlein AJ, Naar AM, Heinzel T, Torchia J, Gloss B, Kurokawa R, Ryan A, Kamel Y, Soderstrom M, Glass CK, Rosenfeld MG (1995) Ligand-independent repression by the thyroid-hormone receptor-mediated by a nuclear receptor co-repressor. Nature 377:397-404

Hu X, Lazar MA (1999) The CoRNR motif controls the recruitment of corepressors by nuclear hormone receptors. Nature 402:93-96

Huang WY, Ramsey KM, Marcheva B, Bass J (2011) Circadian rhythms, sleep, and metabolism. J Clin Invest 121:2133-2141

King DP, Takahashi JS (2000) Molecular genetics of circadian rhythms in mammals. Annu Rev Neurosci 23:713-742

Knutson SK, Chyla BJ, Amann JM, Bhaskara S, Huppert SS, Hiebert SW (2008) Liver-specific deletion of histone deacetylase 3 disrupts metabolic transcriptional networks. EMBO J 27:1017-1028

Kornmann B, Gachon F, Reinke H, Ripperger J, LeMartelot G, Schibler U (2006) The mammalian circadian timing system: from cyclic transcription to rhythmic physiology. FEBS J 273:6

Lam MTY, Cho H, Lesch HP, Gosselin D, Heinz S, Tanaka-Oishi Y, Benner C, Kaikkonen MU, Kim AS, Kosaka M, Lee CY, Watt A, Grossman TR, Rosenfeld MG, Evans RM, Glass CK (2013) Rev-Erbs repress macrophage gene expression by inhibiting enhancer-directed transcription. Nature 498:511-515

Lazar MA, Hodin RA, Darling DS, Chin WW (1989) A novel member of the thyroid steroidhormone receptor family is encoded by the opposite strand of the rat c-erbA-alpha transcriptional unit. Mol Cell Biol 9:1128-1136

Le Martelot G, Claudel T, Gatfield D, Schaad O, Kornmann B, Lo Sasso G, Moschetta A, Schibler U (2009) REV-ERB alpha participates in circadian SREBP signaling and bile acid homeostasis. PLoS Biol 7:e1000181

Marvin KA, Reinking JL, Lee AJ, Pardee K, Krause HM, Burstyn JN (2009) Nuclear receptors homo sapiens Rev-erb beta and Drosophila melanogaster E75 are thiolate-ligated heme proteins which undergo Redox-mediated ligand switching and bind CO and NO. Biochemistry 48:7056-7071

Miyajima N, Horiuchi R, Shibuya Y, Fukushige S, Matsubara K, Toyoshima K, Yamamoto T (1989) 2 erbA homologs encoding proteins with different T3 binding-capacities are transcribed from opposite DNA strands of the same genetic-locus. Cell 57:31-39

Mullican SE, DiSpirito JR, Lazar MA (2013) The orphan nuclear receptors at their 25-year reunion. J Mol Endocrinol 51:T115-T140

Osborn O, Olefsky JM (2012) The cellular and signaling networks linking the immune system and metabolism in disease. Nat Med 18:363-374

Preitner N, Damiola F, Molina LL, Zakany J, Duboule D, Albrecht U, Schibler U (2002) The orphan nuclear receptor REV-ERB alpha controls circadian transcription within the positive limb of the mammalian circadian oscillator. Cell 110:251-260

Raghuram S, Stayrook KR, Huang PX, Rogers PM, Nosie AK, McClure DB, Burris LL, Khorasanizadeh S, Burris TP, Rastinejad F (2007) Identification of heme as the ligand for 
the orphan nuclear receptors REV-ERB alpha and REV-ERB beta. Nat Struct Mol Biol 14:1207-1213

Retnakaran R, Flock G, Giguere V (1994) Identification of RVR, a novel orphan nuclear receptor that acts as a negative transcriptional regulator. Mol Endocrinol 8:1234-1244

Rosbash M, Allada R, Dembinska M, Guo WQ, Le M, Marrus S, Qian Z, Rutila J, Yaglom J, Zeng H (1996) A Drosophila circadian clock. Cold Spring Harbor Symp Quant Biol 61:265-278

Schibler U (2006) Circadian time keeping: the daily ups and downs of genes, cells, and organisms. Prog Brain Res 153:271-282

Solt LA, Wang YJ, Banerjee S, Hughes T, Kojetin DJ, Lundasen T, Shin Y, Liu J, Cameron MD, Noel R, Yoo SH, Takahashi JS, Butler AA, Kamenecka TM, Burris TP (2012) Regulation of circadian behaviour and metabolism by synthetic REV-ERB agonists. Nature 485:62-68

Sun Z, Miller RA, Patel RT, Chen J, Dhir R, Wang H, Zhang DY, Graham MJ, Unterman TG, Shulman GI, Sztalryd C, Bennett MJ, Ahima RS, Birnbaum MJ, Lazar MA (2012) Hepatic Hdac3 promotes gluconeogenesis by repressing lipid synthesis and sequestration. Nat Med 18:934-942

Sun Z, Feng D, Fang B, Mullican SE, You SH, Lim HW, Everett LJ, Nabel CS, Li Y, Selvakumaran V, Won KJ, Lazar MA (2013) Deacetylase-independent function of HDAC3 in transcription and metabolism requires nuclear receptor corepressor. Mol Cell 52:769-782

Ukai-Tadenuma M, Yamada RG, Xu HY, Ripperger JA, Liu AC, Ueda HR (2011) Delay in feedback repression by cryptochrome 1 is required for circadian clock function. Cell 144:268-281

Vieira E, Marroqui L, Batista TM, Caballero-Garrido E, Carneiro EM, Boschero AC, Nadal A, Quesada I (2012) The clock gene Rev-erb alpha regulates pancreatic beta-cell function: modulation by leptin and high-fat diet. Endocrinology 153:592-601

Vieira E, Marroqui L, Figueroa ALC, Merino B, Fernandez-Ruiz R, Nadal A, Burris TP, Gomis R, Quesada I (2013) Involvement of the clock gene Rev-erb alpha in the regulation of glucagon secretion in pancreatic alpha-cells. PLoS One 8:e69939

Wang J, Lazar MA (2008) Bifunctional role of Rev-erb alpha in adipocyte differentiation. Mol Cell Biol 28:2213-2220

Woldt E, Sebti Y, Solt LA, Duhem C, Lancel S, Eeckhoute J, Hesselink MKC, Paquet C, Delhaye S, Shin YS, Kamenecka TM, Schaart G, Lefebvre P, Neviere R, Burris TP, Schrauwen P, Staels B, Duez H (2013) Rev-erb-alpha modulates skeletal muscle oxidative capacity by regulating mitochondrial biogenesis and autophagy. Nat Med 19:1039-1046

Yang XY, Downes M, Yu RT, Bookout AL, He WM, Straume M, Mangelsdorf DJ, Evans RM (2006) Nuclear receptor expression links the circadian clock to metabolism. Cell 126:801-810

Yin L, Lazar MA (2005) The orphan nuclear receptor Rev-erb alpha recruits the N-CoR/histone deacetylase 3 corepressor to regulate the circadian Bmall gene. Mol Endocrinol 19:1452-1459

Yin L, Wu N, Curtin JC, Qatanani M, Szwergold NR, Reid RA, Waitt GM, Parks DJ, Pearce KH, Wisely GB, Lazar MA (2007) Rev-erb alpha, a heme sensor that coordinates metabolic and circadian pathways. Science 318:1786-1789

Yoon HG, Chan DW, Huang ZQ, Li JW, Fondell JD, Qin J, Wong JM (2003) Purification and functional characterization of the human N-CoR complex: the roles of HDAC3, TBL1 and TBLR1. EMBO J 22:1336-1346

Zamir I, Harding HP, Atkins GB, Horlein A, Glass CK, Rosenfeld MG, Lazar MA (1996) A nuclear hormone receptor corepressor mediates transcriptional silencing by receptors with distinct repression domains. Mol Cell Biol 16:5458-5465

Zamir I, Zhang JS, Lazar MA (1997) Stoichiometric and steric principles governing repression by nuclear hormone receptors. Genes Dev 11:835-846

Zhang JS, Kalkum M, Chait BT, Roeder RG (2002) The N-CoR-HDAC3 nuclear receptor corepressor complex inhibits the JNK pathway through the integral subunit GPS2. Mol Cell 9:611-623

Zhao Q, Khorasanizadeh S, Miyoshi Y, Lazar MA, Rastinejad F (1998) Structural elements of an orphan nuclear receptor-DNA complex. Mol Cell 1:849-861 